\title{
Michat Piekarski
}

Instytut Historii Nauki Polskiej Akademii Nauk

\section{Recenzja. Fakty i mity o organach i muzyce organowej Lwowa i Cralicji \\ Сергій Каліберда, Органи Львова і Галичини, Видавництво «Апріорі», Львів 2014, ss. 448, ilustracje, tabele, incleks nazwisk}

Prezentowana książka zawiera opis organów znajdujących się we wschodniej części terytorium dawnej Galicji, jak również działających tam zakładów organmistrzowskich oraz organistów. Jest to pierwsza tego rodzaju praca, dająca wgląd w dzieje kultury muzycznej Lwowa i jego okolic pod kątem organów i muzyki organowej $^{1}$. Publikacja dzieli się pod względem tematycznym na trzy zasadnicze części: w pierwszej (najobszerniejszej) opisane zostały istniejące (dawniej i obecnie) instrumenty znajdujące się w kościołach i salach koncertowych Lwowa oraz bliższych i dalszych miejscowościach (obejmują one także ziemię stanisławowską i tarnopolska), w drugiej opisano lwowskich organmistrzów i ich zakłady organmistrzowskie istniejące w XIX wieku oraz w okresie międzywojennym, w trzeciej dokonano próby ukazania sylwetek działających we Lwowie organistów na przestrzeni kilku stuleci.

Serhij Kaliberda, jak pisze, prace nad książką rozpoczął ponad 15 lat temu. Od wielu lat prowadzi on także stronę internetową katalogującą instrumenty znajdujące się na terytorium Ukrainy (http://www.organy.lviv.ua). Jako cel publikacji określił stworzenie historycznej i kulturalnej podstawy umożliwiającej odrodzenie muzyki i budownictwa organowego na terenach - jak ujął to - Galicji Wschodniej oraz całej Ukrainy. Warto byłoby przy tym, aby autor uściślił, co rozumie pod terminem „Galicja Wschodnia”, ponieważ zastosowane w książce rozgraniczenie nie ma uzasadnienia historycznego, bowiem za kryterium podziału przyjął

\footnotetext{
1 Należy wspomnieć w tym miejscu o pracy Macieja Babnisa, która stanowi rzetelny i obszerny opis kultury muzycznej całej Galicji pod kątem budownictwa organowego. Autor szczególny nacisk postawił w niej na kwestii działalności Jana Śliwińskiego. Zamieszczony w książce katalog obejmuje wyłącznie instrumenty pochodzące z jego firmy. S. Kaliberda na publikację Babnisa niejednokrotnie się powołuje. Zob. M. Babnis, Kultura organowa Galicji, Słupsk 2012.
} 
on granicę wytyczoną w 1945 roku między Polską i ZSRR (czyli obecną granicę między Polską i Ukraina), a więc czas, gdy już od ponad 20 lat nie istniała Galicja jako terytorium administracyjne. Formalnie bowiem Galicja (jako jednostka administracyjna Austrii i Austro-Węgier) nigdy nie była podzielona, zaś za kryterium wyznaczające umownie jej część wschodnią badacze uznają nieraz zasięg sądu apelacyjnego we Lwowie, obejmujący także ziemię przemyską, sanocką i jarosławską - których to terytoriów autor nie uwzględnił. Można dodać, że także historyczne granice archidiecezji lwowskiej i przemyskiej nie pokrywają się z tymi wyznaczonymi przez autora. Ponadto wielokrotnie przenosi też pojęcie „Galicji” na epoki historyczne, w których nie istniał taki byt administracyjny, co ukazuje dzieje tych terytoriów w niewłaściwym kontekście, stwarzając błędną interpretację niektórych faktów (np. odnośnie do czasów sprzed 1772 roku).

Książka rozpoczyna się od dość obszernego wstępu, w którym autor usiłował ukazać kulturę muzyczną Lwowa w aspekcie muzyki organowej. Część ta oraz zamieszczone w dalszych rozdziałach opisy historyczne należą do najsłabszych stron prezentowanej publikacji. Zdumiewają chociażby zdania, w których pojawia się informacja, że początki „doby sztuki polifonicznej” we Lwowie datowane są na czasy Wolfganga Amadeusza Mozarta. Kaliberda pominął w ten sposób choćby całą tradycję renesansową, a przecież to właśnie we Lwowie zachowały się odpisy utworów kompozytorów niderlandzkich z XV i XVI wieku². Autor nie napisał też nic o możliwości udziału organów pod względem zachowanego we Lwowie repertuaru muzycznego. Nie wspomniał na przykład o tak zwanej tabulaturze organowej Łukasza ze Lwowa z XVI wieku. Nie napisał też nic o praktyce muzycznej katedry łacińskiej w aspekcie muzyki organowej. W tym celu warto byłoby skonfrontować treść recenzowanej książki z nieuwzględnionymi przez autora pozycjami bibliograficznymi ${ }^{3}$. Ponadto autor, opisując pobieżnie udział organów w kulturze muzycznej Lwowa, powinien wydzielić zdecydowanie ten ustęp na dwie części: dotyczącą muzyki sakralnej i muzyki świeckiej.

Autor słusznie zwrócił za to uwagę, że w wielu inwentarzach kościelnych więcej miejsca poświęcano dzwonom niż organom, dlatego tym trudniej jest opisać dzieje tego instrumentu. Jego zdaniem Lwów na przełomie XIX i XX wieku był

2 Zob. A. Chybiński, Do historii muzyki we Lwowie w XV wieku, „Kwartalnik Muzyczny” (1929) z. 2, s. 180-181.

3 Zob. m.in. M. Dzieduszycki, Kościót katedralny lwowski obrządku tacińskiego, Lwów 1872; ks. J. Krętosz, Organizacja archidiecezji lwowskiej obrzq̨dku tacińskiego od XVw. do 1772 roku, Lublin 1998; ks. J. Krętosz, Archidiecezja lwowska obrządku tacińskiego w okresie józefnizmu (1772-1815), Katowice 1996; por. M. Piekarski, Z muzycznej przesztości lwowskich kościotów katolickich, [w:] Rocznik Lwowski 2008-2009, Warszawa 2009, s. 81-107. 
jednym $\mathrm{z}$ największych centrów budownictwa organów w Europie. Informacja ta nie została jednak skonfrontowana z żadnymi danymi dotyczącymi innych krajów europejskich. Lwów z pewnością za to mógł stanowić jeden z głównych ośrodków polskiego organmistrzostwa, o czym już autor nie wspomniał. Liczbę organów we Lwowie i Galicji Wschodniej na przełomie XIX i XX wieku autor szacuje na 600-800 instrumentów, z czego 450 potwierdza zgromadzona przez niego dokumentacja.

Najobszerniejsza część pracy (strony 18-360) poświęcona została prezentacji poszczególnych instrumentów, ułożonych według nazw miejscowości. Opis rozpoczyna się od organów mieszczących się w 27 kościołach Lwowa, po czym zaprezentowano także instrumenty znajdujące się $\mathrm{w}$ pozostałych budynkach: Konserwatorium Polskiego Towarzystwa Muzycznego, Teatrze Skarbkowskim, Teatrze Wielkim, Filharmonii, Muzeum Historycznym oraz Muzeum Historii Religii. W zdecydowanej większości opis dotyczy instrumentów już nieistniejących (zgodnie ze stanem sprzed 1945 roku). Autor pisze, że podczas pracy nad książką przeanalizowano wszystkie miejsca, w których we Lwowie mogły kiedyś znajdować się organy, szacując ich liczbę w 1939 roku na ponad 40 instrumentów. Dokonał on także próby opisania wszystkich instrumentów związanych z daną świątynią (np. istniejących w XVIII wieku przed pojawieniem się nowego instrumentu w kolejnym stuleciu). Choć Kaliberda wzmiankuje, że organy wykorzystywano także w kościołach greckokatolickich, nie bierze jednak pod uwagę na przykład katedry św. Jura jako miejsca, gdzie znajdować się mógł taki instrument (na co wskazuje repertuar wykonywany w tej świątyni jeszcze w pierwszej połowie XIX wieku). Opisowi instrumentów towarzyszy próba ujęcia tradycji muzycznej danej świątyni.

Rozdział rozpoczyna się od zaprezentowania organów mieszczących się w katedrze łacińskiej we Lwowie. Trafne jest podkreślenie podobieństwa instrumentu znajdującego się na wielkim chórze z organami w kościele Franciszkanów w Krakowie. Pisząc o katedrze ormiańskiej, Kaliberda posługuje się jedynie informacjami z 1947 roku, gdy doszło do przewiezienia organów z tej świątyni do Uzbeckiej SRR: twierdzi, że o obecności organów w dawniejszych czasach nic nie wiadomo. Szkoda, że autor nie powołał się na jedną z prac poświęconych katedrze ormiańskiej, w której widnieje informacja (oparta o źródło archiwalne) na temat instalacji organów w 1910 roku $^{4}$. Autor ponadto pisze, że organom po II wojnie w zamkniętej katedrze ormiańskiej groziło zniszczenie, dlatego zdecydowano się przewieźć instrument do konserwatorium w Taszkiencie (Uzbecka SRR). Tam

4 Zob. m.in. J. Smirnow, Katedra ormiańska we Lwowie, Lwów 2002. Zob. także A. Chybiński, Do historii muzyki we Lwowie w XV wieku, dz. cyt., s. 180-181. 
jednak los nie okazał się dla nich lepszy, bowiem instrument spłonął, więc warto byłoby w tym miejscu dodać, że decyzja wywiezienia organów ze Lwowa nie uchroniła ich od zniszczenia (jak stało się zresztą w przypadku innych instrumentów), na co autor już nie zwraca uwagi.

Czytając opis instrumentów znajdujących się w dawnym kościele Dominikanów (obecnie cerkiew greckokatolicka), trudno zgodzić się z autorem, że przeprowadzona na początku XXI wieku przebudowa przeniesionego tam instrumentu z kościoła św. Marcina dodała mu „większej dekoracyjności”. To, czego dokonano z tym instrumentem (pochodzącym częściowo z XVIII wieku), można raczej ująć w kategorii dewastacji (nie wnikając już w wątpliwe estetycznie walory nowego prospektu). Efekt wręcz zabawny wywołuje opis dziejów muzyki organowej w dawnym kościele Jezuitów, w którym autor rozważa możliwość, że gry na organach mógł uczyć się w tym kościele uczęszczający do kolegium Bohdan Chmielnicki, na poparcie czego nie posiadamy absolutnie żadnych źródeł. Tego rodzaju rozważaniom autor poświęcił miejsce w książce, zaś całkowicie nie wspomiał o kompozytorach związanych z tym kościołem, tworzących także utwory z udziałem organów, jak Jan Brandt oraz Jan Piotr Habermann.

Pisząc o organach w kościele św. Elżbiety (zamontowanych w latach 20. XX wieku), Kaliberda stwierdza, że nie były one największym instrumentem w międzywojennej Polsce, jak wówczas uważano, jako przykład podając większy instrument znajdujący sie w katedrze w Gdańsku-Oliwie. Autor nie zwrócił jednak uwagi, iż w okresie międzywojennym Gdańsk, w przeciwieństwie do Lwowa, nie znajdował się bezpośrednio w granicach Polski, więc organy lwowskiego kościoła św. Elżbiety słusznie uznawane były za największy instrument w II RP. Zauważalny jest brak informacji na temat tego, gdzie wywieziono organy z kościoła św. Elżbiety po II wojnie, co w przypadku tak olbrzymiego instrumentu jest bardzo zastanawiające. Podobnie Kaliberda nie pisze, co stało się z organami z kościoła Matki Boskiej Śnieżnej, co było jeszcze łatwiejsze do sprawdzenia, skoro instrument istniał tam jeszcze na początku lat 90. Tak samo autor nie pisze nic o tym, co stało się z organami z kościoła św. Mikołaja. Ciekawych szczegółów dowiadujemy się natomiast na temat instrumentów znajdujących się niegdyś w kaplicy sióstr Sacré Coeur oraz w kościele oo. Zmartwychwstańców, które po II wojnie zostały przewiezione do Polski w zmienionych granicach. Szkoda, że autor nie dotarł do informacji, gdzie dokładnie znalazł się instrument z kościoła przy ul. Piekarskiej. Poważne braki zawiera także opis kościoła Benedyktynek. Autor absolutnie nic nie wspomniał o działającym tam w latach 40. XVIII wieku Johannie Philippie Kirnbergerze, uczniu Johanna Sebastiana Bacha, a nie jest to przecież informacja trudna do odnalezienia (dostępna jest choćby w Encyklopedii muzycznej PWM). Uwagę zwraca też całkowite pominięcie kościoła Matki Boskiej Gromnicznej, 
mimo że autor opisuje nieraz o wiele mniejsze kościoły i kaplice, zaś wcześniej (s. 19-23) stwierdził, iż przeanalizował wszystkie miejsca, w których we Lwowie znajdować się mogły organy.

Pewne kontrowersje wzbudza opis organów znajdujących się w kościele św. Marii Magdaleny. Autor raz pisze, że zamontowane tam w latach 30. organy firmy Rieger są typu romantycznego, łączą cechy brzmienia orkiestralnego (s. 91), innym zaś razem stwierdza, że dają one możliwość wykonywania z powodzeniem utworów epoki baroku (s. 92). Są to zatem od strony brzmieniowej organy romantyczne czy barokowe? Organy te, mimo zachwytów autora, w rzeczywistości odbiegają od standardu instrumentów koncertowych. Należy także dodać, że kościół św. Marii Magdaleny wciąż - jak w czasach ZSRR - pozostaje we władaniu Sali Muzyki Organowej i Kameralnej i jego wnętrze jedynie użyczane jest wspólnocie rzymskokatolickiej. Mimo że autor o tym wspomina, to pisząc o stanie znajdującego się tam instrumentu, nie dodaje jednak, że jak każdym organom źle służy im tylko okazjonalne wykorzystywanie (wyłącznie na koncertach), bowiem z powodu zakazu dyrektora Sali Organowej wspólnota rzymskokatolicka używać ich nie może.

Ciekawe informacje możemy natomiast uzyskać na temat organów znajdujących się w budowlach świeckich Lwowa. Dalszy opis w wielu miejscach pozostawia już niestety wiele do życzenia. Przykładowo, autor stwierdza że lwowskie Konserwatorium Galicyjskiego Towarzystwa Muzycznego (po I wojnie Polskie Towarzystwo Muzyczne) „było jednym z najstarszych w Europie” (s. 109), nie zwracając uwagi chociażby na dłuższe tradycje konserwatoriów włoskich. Następnie autor pisze, że w XIX wieku konserwatorium posiadało instrument zbudowany przez Antoniego Sapalskiego z Krakowa, dodając, iż jego Przewodnik dla organistów (Kraków 1880) „był faktycznie szkołą gry na organach” (s. 111). Nie jest to jednak zgodne z prawdą, bowiem w książce tej samej grze organowej poświęcono zaledwie 7 stron, całość zaś składa się ze wskazówek, ,jak organy w dobrym stanie utrzymać". Kaliberda wystrzegłby się takiego błędu, gdyby samodzielnie dotarł do pozycji, na którą się powołuje. W innym miejscu pisze, że Rudolf Szwarc (wykładowca klasy organów Konserwatorium GTM) był „wspaniałym organistą” - przy takich określeniach warto jednak powoływać się na źródła, bowiem możemy tu podejrzewać autora jedynie o bezzasadną egzaltację. Ciekawe informacje znajdujemy na temat organów skonstruowanych w 1929 roku przez Rudolfa Haasa w sali koncertowej Konserwatorium. Autor dodaje, że zostały one rozebrane w 1952 roku, jednak część instrumentu przetrwać miała do dziś - nie dowiadujemy się już niestety, gdzie mogłaby się ona znajdować (czy chodzi o ewentualne uzupełnienie instrumentu przeniesionego tam po wojnie z kościoła Dominikanów?). Należy też zauważyć, że autor nieraz dzięki swej wnikliwości koryguje 
informacje zawarte $\mathrm{w}$ dotychczasowej literaturze przedmiotu, pisząc na przykład, że istniejące do 1952 roku organy w sali koncertowej Konserwatorium były firmy Haasa, a nie Riegera.

Autor relacjonuje, że w 1955 roku do utworzonej po II wojnie Filharmonii Lwowskiej, otrzymującej pomieszczenia dawnego PTM, przeniesiono organy z kościoła Dominikanów. Jego zdaniem organy te „stały się najlepszym instrumentem koncertowym na Ukrainie" (s. 118). Trudno stwierdzić, na jakiej podstawie wyrażona została ta opinia. Wiarygodność jej podważa już zamieszczone $\mathrm{w}$ innym miejscu stwierdzenie samego autora, piszącego że organy te posiadały rejestry, które „grały głucho”, zaś mechanika okazywała niedociągnięcia. Zresztą instrument już w latach 60 . był niezdatny do użytku. W takim razie „najlepsze koncertowe organy Ukrainy" przeniesione do filharmonii z kościoła Dominikanów zdolne były grać jedynie przez 8 lat. Należało przy tym zastanowić się, dlaczego tak się działo, skoro wcześniej instrument ten mógł przez o wiele dłuższy czas służyć w kościele. Takiego pytania autor już jednak nie stawia.

Opisowi organów w Teatrze Skarbkowskim przydałaby się odpowiednia fotografia, dostępna choćby w czasopiśmie z epoki. Cenne informacje dotyczą za to organów znajdujących się niegdyś w Teatrze Wielkim, które zdemontowano dopiero w latach 80., podczas remontu wyrzucając je na złom. Na końcu opisu organów znajdujących się we Lwowie autor wspomniał też o dwóch pozytywach znajdujących się w zbiorach Muzeum Historycznego Miasta Lwowa, które pochodzą z kolekcji Władysława Łozińskiego.

W kolejnej części książki zamieszczony został opis organów znajdujących się (dawniej i obecnie) na terenie obwodów lwowskiego (26 miejscowości), iwanofrankiwskiego (3) i tarnopolskiego (13). Szkoda, że w publikacji nie zamieszczono mapy, aby czytelnik mógł dokładnie sprawdzić, gdzie znajduje się dana miejscowość. Opis obejmuje m.in. takie miejscowości jak Gródek (d. Gródek Jagielloński), Żółkiew, Złoczów, Mościska, Sambor, Stryj, Truskawiec. Należy zwrócić uwagę na dokonaną przez autora dokładną penetrację instrumentów znajdujących się w Gródku - organów budowanych w kościele podczas okupacji hitlerowskiej, które po wojnie trafiły do Opola oraz pozytywu niewiadomego pochodzenia przechowywanego w piwnicy obecnego budynku rady miejskiej Gródka. W rozdziale tym całkowicie bezzasadny jest za to obszerny opis pożaru kościoła w Doliniwce. Zresztą nie tylko w tym miejscu autor zamiast stworzenia zamierzonego katalogu instrumentów próbował zamieścić wszystkie znane mu i nieuporządkowane informacje dotyczące danej świątyni, nawet całkowicie zbędne dla prezentowanej pracy. Autor np. cytuje (s. 148) gazetę „Wysoki Zamek” z 24.10.2006, zamieszczając obszerny opis wrażeń parafian po pożarze kościoła w Doliniwce. Doprawdy trudno stwierdzić, czemu ma to służyć w książce po- 
święconej organom Lwowa i Galicji. Przez brak jasnej koncepcji pracy Kaliberda nieraz znacznie oddala się od zagadnienia sugerowanego w jej tytule.

W rozdziale tym opisane są także nieliczne instrumenty zrekonstruowane po 1991 roku, jak na przykład w kościele w Żółkwi, gdzie w tym celu wykorzystano organy sprowadzone z okolic Genewy. Prace te odbywały się z ramienia Ministerstwa Kultury w Warszawie, na co słusznie autor zwrócił uwagę. Ciekawe informacje dotyczą wzniesionych na nowo organów w kościele w Truskawcu, które faktycznie należą do jednych z lepszych instrumentów w obecnych granicach Ukrainy, o czym autor jednak już nie wspomina.

Po opisie organów w obwodach iwanofrankowskim i tarnopolskim autor zamieścił podrozdział „nieistniejące organy Galicji”. Zastanawiające jest, według jakich kryteriów instrumenty rozróżniono na „istniejące” oraz „nieistniejące”, skoro jako „organy istniejące” w wielu przypadkach uwzględnione zostały instrumenty zachowane fragmentarycznie, nieraz z samą tylko obudową prospektu. Wśród organów nieistniejących autor wymienia ponad 300 instrumentów. Ich opis zajmuje znaczną część książki (ss. 270-360).

Kolejny rozdział poświęcony został działającym we Lwowie organmistrzom i zakładom organmistrzowskim (ss. 362-400). Autor zwraca uwagę, że z historią Lwowa związanych jest niemało nazwisk organmistrzów. Pisze, że wielu z nich mogłoby stać się dumą narodu, do jakiego należeli, jednak w dalszej części pracy nie wspomina, że zdecydowana większość lwowskich organmistrzów była narodowości polskiej. W jednym akapicie wymienione zostały imiona budowniczych organów od XVI do XVIII wieku. Następnie szczegółowo omówiono (wraz z ich zakładami organmistrzowskimi) postaci działających w XIX wieku organmistrzów: Jakuba Kramkowskiego, Romana Ducheńskiego, Andrzeja Sitnickiego, Jana Grocholskiego, Antoniego Klementa, Jana Śliwińskiego, Tomasza Falla, Rudolfa Haase, Franciszka Gajdę, Mieczysława Janiszewskiego, Bronisława Markiewicza, Mikołaja Sojkowskiego, Bartłomieja Ziemiańskiego, Franciszka Zucha, Wacława Biernackiego, Ignacego Żebrowskiego, Aleksandra Żebrowskiego, Kazimierza Żebrowskiego. Uwagę zwraca to, że wiele wymienionych nazwisk nie pojawia się w innych pracach, dzięki czemu prezentowana książka stanowi uzupełnienie choćby dla opublikowanego ponad 50 lat temu Stownika muzyków polskich.

Niemało miejsca autor poświęcił postaci Jana Śliwińskiego, który w Paryżu terminował w słynnej firmie organmistrzowskiej Aristide’a Cavaillé-Colla, zaś we Lwowie założył Fabrykę Organów Kościelnych i Harmonium, z której 110 instrumentów znajdowało się na terytorium całej Galicji. Postacią Jana Sliwińskiego Kaliberda zajmował się już od dłuższego czasu, uzyskując wiele informacji na jego temat. Na uwagę zasługuje dokładny wykaz organów wykonanych w fabryce Jana Śliwińskiego, obejmujący w większości instrumenty już nieistniejące. Podobnie 
szczegółowy wykaz dotyczy organów wybudowanych przez członków rodziny Żebrowskich. Zadziwiające jest jednak to, że autor, pisząc o organach Śliwińskiego, stwierdza, że wykonano je także dla „ukraińskiej części Galicji” (zwłaszcza że podziału takiego nie było, o czym już wspomniano), a przecież z jego instrumentów korzystała przede wszystkim społeczność polska, bowiem Ukraińcy tradycyjnie przynależeli do Kościoła greckokatolickiego, nieużywającego już w tym okresie organów w cerkwiach. Związek organów z kulturą ukraińską był zatem bardzo luźny, niezależnie od miejscowości, w której zostały one zamontowane. $\mathrm{Z}$ tego względu stwierdzenie autora jest wyjątkowo niejasne.

Ostatni rozdział poświęcony został organistom działającym we Lwowie. Posiada on zdecydowanie najwięcej braków i nieścisłości. Autor usiłował dokonać przeglądu nazwisk muzyków działających w mieście od średniowiecza po wiek XX. Nic nie wspomina przy tym o tzw. Łukaszu ze Lwowa (o czym już była mowa). Wśród XVI-wiecznych organistów wymienia Marcina Leopolitę. Nie ma jednak przecież informacji potwierdzonej źródłowo, że działający prawdopodobnie na dworze Zygmunta Augusta muzyk pochodzący ze Lwowa w ogóle kiedykolwiek zatrudniony był $\mathrm{w}$ tym mieście, choć zdaniem autora miało to miejsce w roku 1564. Jest to częsty błąd pojawiający się zwłaszcza w ukraińskiej literaturze przedmiotu. Po Leopolicie autor przechodzi do omawiania organistów działających w wieku XIX i XX. Zadziwiająca jest tu niemal 300-letnia luka, której autor nie próbuje wytłumaczyć. Poważnym uchybieniem jest tu brak wzmianki o Johannie Philippie Kirnbergerze.

Kolejni wymienieni przez autora organiści związani byli z Galicyjskim Towarzystwem Muzycznym oraz Konserwatorium Galicyjskiego Towarzystwa Muzycznego (późniejszego Polskiego Towarzystwa Muzycznego): Gorgon Traugott, Rudolf Szwarc i Mieczysław Sołtys. Brakuje tu nazwiska Józefa Rubingera, wykładowcy klasy organów w Konserwatorium Polskiego Towarzystwa Muzycznego po śmierci Mieczysława Sołtysa. Szkoda także, że autor nie dotarł do informacji na temat Władysława Jurkiewicza, prowadzącego klasę organów w Lwowskim Instytucie Muzycznym, widoczny jest też brak nazwisk nauczycieli prowadzących zajęcia w katedralnej szkole organistowskiej. Opisu sylwetek artystycznych lwowskich organistów autor dokonuje bez żadnej koncepcji, poświęcając na przykład miejsce na zamieszczenie informacji o operach Sołtysa, za to nie omawiając jego Canzony op. 23 na organy, co byłoby o wiele bardziej wskazane. Kolejni omówieni organiści to działający w okresie międzywojennym i nieraz także powojennym: Michał Woźny (z niewiadomych przyczyn tylko jego nazwisko podano również w transkrypcji na alfabet łaciński), Tadeusz Majerski, Tadeusz Mahl, Jan Ranged-Śmigielski i Józef Nowakowski. Szkoda, że autor nie podaje źródeł, z których zaczerpnął informacje dotyczące omawianych organistów. Bardzo zdawkowo 
opisana została postać Józefa Nowakowskiego, wieloletniego organisty katedry Lwowskiej, który pełnił w tej świątyni swoje obowiązki także po II wojnie światowej. W dalszym ciągu pozostaje on przez to postacią zapomnianą, choć autor zwraca uwagę, że jego biografia powinna zostać napisana. Autor nie wspomniał także, że obecny organista lwowskiej katedry, Bronisław Pacan, jako uczeń Nowakowskiego kontynuuje tradycje muzyczne tej świątyni. Nie pojawiły się też ani razu nazwiska organistów działających w dwóch pozostałych rzymskokatolickich kościołach Lwowa, nieodebranych wiernym przez władzę sowiecką: Andrzeja Nikodemowicza - kompozytora związanego z kościołem św. Marii Magdaleny (zamienionym później na salę koncertowa) - oraz Andrzeja Taraska - organisty i kompozytora pracującego w kościele św. Antoniego (obok katedry czynnym nieprzerwanie do dziś). Na końcu autor omówił sylwetki organistów narodowości ukraińskiej, którzy działali we Lwowie po II wojnie światowej: Arsenija Kotlarewskiego, Samuela Dajcza, Witalija Piwnowa i Nadii Welyczko. Przedstawił także swoje pomysły dotyczące ożywienia we Lwowie wykonawstwa muzyki organowej, obejmujące m.in. przeniesienie organów z filharmonii na swoje dawne miejsce w kościele podominikańskim oraz budowę nowego instrumentu w sali koncertowej, a także powstania klasy organów we Lwowskiej Akademii Muzycznej im. Mykoły Łysenki.

Omawiana publikacja zasługuje na uwagę przede wszystkim ze względu na podjęty w niej temat. Uwagę zwracają liczne cenne ilustracje, zwłaszcza nieistniejących już instrumentów wraz z podaną ich dyspozycją. Całość posiada też jednak wiele uchybień, takich jak zwłaszcza nieprzemyślana koncepcja pracy. Rażące jest, gdy w danych podrozdziałach pojawiają się informacje całkowicie niezwiązane z sugerowaną treścią - np. gdy dopiero przy okazji opisu kościoła w Doliniwce autor zamieszcza ogólne dane na temat organów zachowanych do dziś na terytorium Ukrainy, co powinno mieć miejsce we wstępie. Książka traci też naukowy charakter przez liczne wstawki o charakterze publicystycznym. Jaskrawym przykładem jest zamieszczenie całkowicie zbędnego (a obszernego) opisu pożaru kościoła w Doliniwce.

Brak też wielu wniosków - autor na przykład nie zauważa, że w większości przypadków organy uratowane zostały od zniszczenia tam, gdzie pozostałym po II wojnie światowej Polakom nie odebrano kościoła. Najwięcej nieścisłości zawiera jednak opis tradycji muzycznych danych świątyń, spowodowany chociażby niedostatecznym zaznajomieniem się autora z literaturą przedmiotu. W związku z tym albo należałoby znacznie opis ten uzupełnić, albo z niego całkowicie zrezy- 
gnować, koncentrując się wyłącznie na zaprezentowaniu samych organów Lwowa i jego okolic.

Nieprzemyślana koncepcja redakcyjna widoczna jest także przy opisie poszczególnych instrumentów. Zauważalny jest nieraz brak odpowiedniej tabeli z dyspozycją omawianych organów, co zastanawia zwłaszcza w przypadku istniejących do dziś instrumentów (np. w Nowym Mieście i Pnikucie). Innym razem całkowicie niepotrzebnie przy opisie organów pojawia się cytowana w całości (w przekładzie na język ukraiński) treść dokumentów archiwalnych, która rozbija zwartość opisu instrumentów. Narrację niepotrzebnie rozbija także umieszczanie informacji na temat współczesnego wykonawstwa organowego w rozdziałach poświęconych opisowi konkretnych instrumentów. Lepiej byłoby, gdyby autor wydzielił osobne miejsce na ewentualny opis przeszłości i teraźniejszości muzycznej danych świątyń oraz na zaprezentowanie samych instrumentów. Mimo omówionych powyżej uchybień prezentowana książka ma cenne walory wyłącznie jako katalog instrumentów, co jest bez wątpienia zasługującym na uwagę dokonaniem autora. 